\title{
PENERAPAN BANTUAN HUKUM BAGI MASYARAKAT KURANG MAMPU DI INDONESIA
}

\author{
Angga $^{1}$, Ridwan Arifin ${ }^{2}$ \\ Fakultas Hukum Universitas Negeri Semarang \\ Jln. Kampus Timur, Sekaran, Gunung Pati, Semarang, Jawa Tengah, 50229, \\ Indonesia \\ email: angga.brada@gmail.com
}

\begin{abstract}
Legal assistance is the constitutional right of every citizen to guarantee protection and equality before the law, as a means of recognizing human rights. Obtaining legal assistance for everyone is the realization of access to justice as the implementation of legal protection guarantees, and guarantees equality before the law. This is in accordance with the concept of legal assistance that is associated with the ideals of the welfare state. Legal assistance is also an important instrument in the Criminal Justice System because it is part of the protection of human rights for every individual, including the right to legal assistance. The right to legal assistance is one of the most important rights that every citizen has. Because in every legal process, especially criminal law, the prosecutors cannot possibly defend themselves. And for disadvantaged people, the government has prepared legal assistance for free or free. But there are still many underprivileged people who do not know this yet so they feel they are not helped by the government. This article explain more about what is legal aid, how to apply for legal assistance, and who can get free or free legal assistance.
\end{abstract}

Keywords: Legal Aid, Poor Communities, Community Rights

\begin{abstract}
ABSTRAK
Bantuan hukum merupakan hak konstitusional setiap warga negara atas jaminan perlindungan dan persamaan di depan hukum, sebagai sarana pengakuan Hak Asasi Manusia (HAM). Mendapatkan bantuan hukum bagi setiap orang adalah perwujudan akses terhadap keadilan sebagai implementasi dari jaminan perlindungan hukum, dan jaminan persamaan di depan hukum. Hal ini sesuai dengan konsep bantuan hukum yang dihubungkan dengan cita-cita negara kesejahteraan.Bantuan hukum juga merupakan instrumen penting dalam Sistem Peradilan Pidana karena merupakan bagian dari perlindungan HAM bagi setiap individu, termasuk hak atas bantuan hukum.Hak atas bantuan hukum adalah salah satu hak yang terpenting yang dimiliki oleh setiap warga negara. Karena dalam setiap proses hukum, khususnya hukum pidana, para terdakwah tidak mungkin bisa untuk membela dirinya sendiri. Bagi masyarakat yang kurang mampu, pemerintah sudah menyiapkan bantuan hukum secara cuma-cuma atau gratis.Namun masih banyak masyarakat kurang mampu yang belum mengetahui hal tersebut sehingga mereka merasa tidak dibantu oleh pemerintah. Tulisan ini menjelaskan lebih jauh tentang apa itu bantuan hukum, bagaimana cara mengajukan bantuan hukum, dan siapa saja yang bisa mendapat bantuan hukum secara cuma-cuma atau gratis.
\end{abstract}

Kata Kunci: Bantuan Hukum, Masyarakat Miskin, Hak Masyarakat

${ }^{1}$ Submission : 15-2-2019 I Review : 6-3-2019 I Production : 28 - 2- 2019 


\section{Pendahuluan}

Sistem hukum Indonesia dan Undang-Undang Dasar 1945 menjamin adanya persamaan dihadapan hukum seperti yang tertuang dalam Pasal 27 ayat (1) Undang-Undang Dasar 1945 disebutkan "Setiap warga Negara bersamaan kedudukannya dalam hukum dan pemerintahan itu dengan tidak ada kecualinya". ${ }^{2}$ Salah satu upaya untuk mewujudkan keadilan atau kesamaaa kedudukan dalam hukum yaitu dengan adanya bantuan hukum bagi setiap warga negara yang terlibat dalam kasus hukum. Menurut Soerjono Soekanto, bantuan hukum pada pokoknya memiliki arti bantuan hukum yang diberikan oleh para ahli bagi warga masyarakat yang memerlukan untuk mewujudkan hak-haknya serta juga mendapatkan perlindungan hukum yang wajar. $^{3}$

Jaminan atas hak konstitusional tersebut belum mendapatkan perhatian secara memadai sehingga dibentuknya Undang-Undang Nomor 16 Tahun 2011 tentang Bantuan Hukum (UUBH) menjadi dasar bagi negara untuk menjamin warga negara, khususnya bagi orang atau kelompok orang miskin untuk mendapatkan akses keadilan dan kesamaan dihadapan hukum. ${ }^{4}$ Selain itu itu, juga terdapat Undang-Undang Nomor 18 Tahun 2003 tentang Advokat yang dalam ketentuannya mewajibkan seorang advokat atau penasihat hukum untuk memberikan bantuan hukum kepada masyarakat yang kurang mampu secara cuma-cuma berdasarkan syarat-syarat yang diatur dalam UndangUndang. Jika advokat tidak melakukan tugasnya untuk memberi bantuan hukum terhadap masyarakat kurang mampu, maka advokat tersebut akan dikenakan sanksi sesuai Undang-Undang yang berlaku.

Lembaga Bantuan Hukum atau dapat disebut dengan (LBH) merupakan perwujudan dari salah satu asas penting yang dianut Kitab Undang-Undang Hukum Acara Pidana atau bisa disebut (KUHAP) yaitu asas accusatoir atau

\footnotetext{
${ }^{2}$ Pasal 27 ayat (1) Undang-Undang Dasar Negara Republik Indonesia Tahun 1945

3 IGN. Ridwan Widyadharma, Profesional Hukum Dalam Pemberian Bantuan Hukum (Semarang: Badan Penerbit Universitas Diponegoro, 2010). Hlm. 26

${ }^{4}$ Yusuf Saefudin, "Implementasi Pemberian Bantuan Hukum Bagi Rakyat Miskin Di Jawa Tengah Berdasarkan Undang-Undang Nomor 16 Tahun 2011 Tentang Bantuan Hukum,” Jurnal Idea Hukum 1, no. 1 (2015). Hlm. 65-66
} 
asas yang menunjukkan bahwa seorang terdakwah yang diperiksa di persidangan tidaklah dianggap sebagai objek, melainkan dianggap sebagai subjek. Asas accusatoir telah memperlihatkan suatu pemeriksaan terbuka dimana setiap orang dapat menghadiri atau menyaksikan jalannya pemeriksaan. Terdakwa mempunyai hak yang sama nilainya dengan penuntut umum, sedangkan hakim berada di atas kedua belah pihak untuk menyelesaikan perkara pidana menurut hukum pidana yang berlaku.

Masalah bantuan hukum tentu bagi kalangan ekonomi atas dapat menunjuk advokat jika dibutuhkan untuk membela kepentingannya, sedangkan bagi kalangan ekonomi kebawah yang tidak memiliki kemampuan secara materil tidak mampu menunjuk advokat sebagaimana yang dilakukan oleh kelompok yang memiliki kemampuan secara ekonomi. Menjamin hak masyarakat mendapatkan bantuan hukum khususnya bagi masyarakat miskin adalah kewajiban dari negara. Hal ini sebagai konsekunesi logis dan pengakuan negara yang mengatakan "Segala warga negara bersamaan kedudukannya di depan hukum dan pemerintahan dan wajib menjunjung hukum dan pemerintahan jtu dengan tidak ada kecualinya. ${ }^{5}$ Kemudian dalam Pasal 34 ayat (11) UUD 1945 menegaskan "Fakir miskin dan anak-anak yang telantar dipelihara oleh Negara". Hal ini secara ekstensif dapat ditafsirkan bahwa negara bertanggung jawab memberikan perlindungan dan pengakuan terhadap hak-hak fakir miskin. ${ }^{6}$

Undang-Undang Nomor 12 Tahun 2005 tentang Kovenan Internasional Hak-Hak Sipil dan Politik mengakui hak atas bantuan hukum dan hak atas Advokat dan memerintahkan negara untuk menyediakan Advokat yang memberikaan bantuan hukum secara efektif untuk masyarakat miskin ketika kepentingan keadilan mensyaratkannya.

\footnotetext{
${ }^{5}$ Pasal 27 ayat (1) Undang-Undang Dasar Negara Republik Indonesia Tahun 1945

${ }^{6}$ Frans Hendra Winarta, Hak Konstitusional Fakir Miskin Untuk Memperoleh Bantuan Hukum Dalam Rangka Pembangunan Hukum Nasional (Semarang: Universitas Padjajaran, 2007). Hlm. 7
} 
Memenuhi tuntutan konstitusional tersebut, Pasal 22 Undang-Undang Nomor 18 Tahun 2003 tentang Advokat untuk selanjutnya disebut (UU Advokat) telah mengakomodirnya, bahwa advokat "wajib" memberikan bantuan hukum secara cuma-cuma kepada pencari keadilan yang tidak mampu. Prinsip tersebut merupakan turunan prinsip negara hukum (rechtstaat) dan asas equality before the law dalam UUD 1945 yakni Pasal 27 ayat (11) yang menyebutkan bahwa setiap warga negara sama kedudukannya di depan hukum dengan tidak ada kecualinya, dan Pasal 28D ayat (1) yang berbunyi "Setiap orang berhak atas pengakuan, jaminan, perlindungan, dan kepastian hukum yang adil serta perlakuan yang sama didepan hukum". ${ }^{7}$

Instrumen internasional, jaminan dan perlindungan hukum serta bantuan hukum diatur dalam Deklarasi Universal Hak-Hak Asasi Manusia tahun 1948 yang mengakui hak setiap orang untuk diakui di depan hukum dimana saja ia berada dan jaminan setiap orang sama didepan hukum dan mempunyai hak atas perlindungan hukum yang sama tanpa diskriminasi. Dalam Konvensi Hak-Hak Sipil dan politik 1966 Pasal 14 ayat (3) huruf D disebutkan bahwa kewajiban bantuan hukum cuma-cuma oleh negara yang menyatakan, "Dalam menentukan tindak pidana yang dituduhkan padanya, setiap orang berhak atas jaminan-jaminan minimal berikut ini, dalam persamaan yang penuh untuk membela diri secara langsung atau melalui pembela yarg dipilihnya sendiri, untuk diberitahukan tentang hak ini bila ia tidak mempunyai pembela dan untuk mendapatkan bantuan hukum demi kepentingan keadilan, dan tanpa membayar jika ia tidak memiliki dana yang cukup untuk membayarnya”.

Penelitian yang membahas tentang Penerapan Bantuan Hukum Bagi Masyarakat Kurang Mampu di Indonesia sudah cukup banyak dilakukan oleh para peneliti terdahulu. Berdasarkan hasil penelusuran terhadap beberapa literatur yang telah dilakukan, maka setidaknya ditemukan beberapa literatur yang membahas mengenai permasalahan ini, seperti Andan Adi Satriawan, Upik Hamidah, Satria Prayoga dengan judul Implementasi Bantuan Hukum

${ }^{7}$ Philipus M Hadjon, Perlindungan Hukum Bagi Rakyat Di Indonesia (Bandung: Bina Ilmu, 1987). Hlm. 76 
pada Masyarakat Miskin di Kota Bandar Lampung (Studi di Lembaga Bantuan Hukum Bandar Lampung) pada tahun 2014 yang dalam penelitiannya tersebut membahas tentang implementasi bantuan hukum pada masyarakat miskin di Kota Bandar Lampung dan faktor-faktor penghambat Implementasi bantuan hukum pada masyarakat miskin di Kota Bandar Lampung. ${ }^{8}$ Adapun hasil penelitian menjelaskan implementasi bantuan hukum pada masyarakat miskin di Kota Bandar Lampung sampai saat ini belum optimal karena belum bisa dirasakan oleh seluruh lapisan masyarakat khususnya masyarakat miskin di Bandar Lampung. Faktor-Faktor yang menjadi penghambat implementasi bantuan hukum pada masyarakat miskin di Kota Bandar Lampung antara lain yaitu, (a) Faktor hukum sendiri meliputi masih minimnya payung hukum untuk masalah bantuan hukum, (b) Faktor SDM yang berkaitan dengan kualitas dan kuantitas pemberi bantuan hokum, (c) Faktor dari kebudayaan masyarakat sendiri berkaitan dengan kurangnya pengetahuan masyarakat tentang bantuan hukum dan masih malasnya masyarakat untuk melapor pada Lembaga Bantuan Hukum. ${ }^{9}$

Kedua, Yusuf Saefudin dengan judul Implementasi Pemberian Bantuan Hukum Bagi Rakyat Miskin di Jawa Tengah Berdasarkan Undang-Undang Nomor 16 Tahun 2011 tentang Bantuan Hukum pada tahun 2015 yang dalam penelitiannya tersebut membahas tentang implementasi pemberian bantuan hukum bagi rakyat miskin di Jawa Tengah sudah sesuai dengan UndangUndang Nomor 16 Tahun 2011 tentang Bantuan Hukum serta hambatan dalam implementasi pemberian bantuan hukum bagi rakyat miskin di Jawa Tengah tersebut. ${ }^{10}$ Adapun hasil penelitian ini menjelaskan bahwa implementasi bantuan hukum bagi rakyat miskin di Jawa Tengah belum terimplementasi dengan Hal ini dikarenakan beberapa faktor, antara lain (1) Pengawasan belum

${ }^{8}$ Andan Adi Satriawan, Upik Hamidah, and Satria Prayoga, "Implementasi Bantuan Hukum Pada Masyarakat Miskin Di Kota Bandar Lampung (Studi Di Lembaga Bantuan Hukum Bandar Lampung)," Jurnal Online FH UNILA 1, no. 3 (2014). Hlm. 5

${ }^{9}$ Satriawan, Hamidah, and Prayoga. Hlm. 5

${ }^{10}$ Yusuf Saefudin, "Implementasi Pemberian Bantuan Hukum Bagi Rakyat Miskin Di Jawa Tengah Berdasarkan Undang-Undang Nomor 16 Tahun 2011 Tentang Bantuan Hukum,” Jurnal Idea Hukum 1, no. 1 (2015). Hlm. 75 
maksimal (2) Masih banyak orang miskin yang tidak tahu adanya program bantuan hukum (3) Masih banyak orang miskin yang berperkara tidak mendapatkan bantuan hukum (4) Proses reimbursement yang sering terlambat (5) Ego sektoral lembaga hukum yang terkait masih tinggi dan (6) Administrasi reimbursement yang terlalu susah belum efektif dan efisien. Faktor-faktor penghambat pelaksanaan bantuan hukum bagi rakyat miskin di Jawa Tengah ada 3 (tiga) faktor, yakni (1) Faktor substansi hukum (legal substance) (2) Struktur hukum (legal structure) dan (3) Budaya hukum (legal culture). ${ }^{11}$

Mencermati dua penelitian terdahulu di atas, maka dapat dikatakan penelitian ini berbeda dengan penelitian tersebut, adapun unsur kebaruan dalam penelitian ini terletak pada kajian isu hukum masing-masing penelitian, yang dalam kajian ini membahas prosedur untuk mendapatkan bantuan hukum serta siapa saja yang berhak mendapat dan memberikan bantuan hukum.

\section{Rumusan Masalah}

Berdasarkan penjalasan di atas, maka diketahui yang menjadi permasalahan dalam penelitian ini adalah bagaimana prosedur untuk mendapatkan bantuan hukum serta siapa saja yang berhak mendapat dan memberikan bantuan hukum.

\section{Tujuan Penelitian}

Tujuan peneltian ini adalah untuk mengkaji secara mendalam prosedur untuk mendapatkan bantuan hukum serta menganalisa siapa saja yang berhak mendapat dan memberikan bantuan hukum.

\section{Metode Penelitian}

Kajian ini didasarkan pada penelitian hukum normatif yaitu suatu penelitian yang dilakukan dengan mengkaji dan menganalisa bahan-bahan hukum dan isu-isu hukum yang terkait dengan permasalahan yang diteliti.

\footnotetext{
${ }^{11}$ Yusuf Saefudin. Hlm. 75
} 
Penelitian hukum dilakukan untuk memecahkan persoalan yang timbul, sedangkan hasil yang akan dicapai adalah berupa deskripsi mengenai apa yang seyogianya dilakukan untuk menjawab permasalahan tersebut.

Pendekatan yang digunakan dalam penelitian ini adalah pendekatan Undang-Undang (statute approach) dan pendekatan konseptual (conceptual approach). Pendekatan Undang-Undang (statute approach) dilakukan dengan menelaah semua Undang-Undang dan regulasi yang bersangkut paut dengan isu hukum yang sedang dianalisis.

Kemudian pendekatan konseptual merupakan pendekatan yang beranjak dari pandangan-pandangan dan doktrin-doktrin dalam ilmu hukum. Melalui penelaahan atas pandangan dan doktrin tersebut maka akan ditemukan ide yang melahirkan pengertian-pengertian hukum, konsep-konsep hukum dan asas-asas hukum yang relevan dengan isu hukum yang dihadapi dalam penelitian ini.

Sumber hukum yang dipergunakan dalam penelitian ini terdiri dari Bahan Hukum Primer yaitu bahan hukum yang bersifat otoritatif, artinya bahan hukum tersebut mempunyai otoritas, yang terdiri dari peraturan perundang-undangan, catatan-catatan resmi atau risalah-risalah terkait dengan pembahasan suatu Undang-Undang. Dalam penelitian ini, perundangundangan sebagai bahan hukum primer adalah Undang-Undang Nomor 18 Tahun 2003 tentang Advokat, Undang-Undang Nomor 16 Tahun 2011 tentang Bantuan Hukum serta Peraturan Pemerintah Nomor 43 Tahun 2013 tentang Syarat dan Tata Cara Pemberian Bantuan Hukum dan Penyaluran Dana Bantuan Hukum.

Kemudian Bahan hukum sekunder, meliputi semua publikasi tentang hukum yang bukan merupakan dokumen resmi. Publikasi tentang hukum ini meliputi buku-buku teks, skripsi hukum, kamus hukum, komentar atas putusan pengadilan serta opini hukum dari para ahli yang dipublikasikan melalui jurnal, majalah atau internet/website. 
Teknik Pengumpulan data yang akan digunakan dalam penelitian hukum ini adalah studi kepustakaan yang terbatas pada penggunaan dokumen dan bahan pustaka. Pengumpulan data dilakukan dengan cara mengumpulkan datadata tertulis yang berkaitan dengan masalah yang diteliti.

Analisa bahan hukum dalam penilitian ini menggunakan penalaran deduktif, yaitu menganalisa beberapa premis hukum dalam kajian ini untuk ditarik pada sebuah satu kesimpulan yang dapat menggambarkan jawaban dari rumusan masalah di atas.

\section{Hasil Penelitian dan Pembahasan}

\subsection{Prosedur Untuk Mengajukan Bantuan Hukum}

Bantuan hukum merupakan instrumen penting dalam Sistem Peradilan Pidana karena merupakan suatu bentuk dari perlindungan HAM bagi setiap manusia, termasuk hak atas bantuan hukum. Hak atas bantuan hukum merupakan salah satu hak terpenting yang dimiliki oleh setiap warga negara karena dalam setiap proses hukum, khususnya hukum pidana, pada umumnya setiap orang yang di tetapkan sebagai tertuduh dalam suatu perkara pidana, tidaklah mungkin dapat melakukan pembelaan sendiri dalam suatu proses hukum dan dalam pemeriksaan hukum terhadapnya. Dengan demikian tidaklah mungkin seorang tersangka dalam suatu tindak pidana melakukan pembelaan terhadap dirinya sendiri dalam suatu proses hukum pemeriksaan dirinya sedangkan dia adalah seorang tersangka dalam suatu tindak pidana yang dituduhkan kepadanya tersebut. Oleh karena itu terdakwa berhak memperoleh bantuan hukum.

Menurut Undang-Undang Nomor 16 Tahun 2011 tentang Bantuan Hukum bisa disebut dengan (UU Bantuan Hukum), bantuan hukum merupakan sebuah jasa hukum yang diberikan oleh pemberi bantuan hukum secara cuma-cuma kepada penerima bantuan hukum yang menghadapi masalah hukum. 
Terdapat dua istilah terkait dengan bantuan hukum yaitu legal aid dan legal assistance. Istilah legal aid biasanya dipergunakan untuk menunjukkan pengertian bantuan hukum dalam arti sempit, yaitu pemberian jasa-jasa di bidang hukum kepada seseorang yang terlibat dalam suatu perkara secara cuma-cuma khususnya bagi mereka yang tidak mampu. Sedangkan pengertian legal assistance dipergunakan untuk menunjukkan pengertian bantuan hukum dalam arti luas, karena di samping bantuan hukum terhadap mereka yang tidak mampu, juga pemberian bantuan hukum yang dilakukan oleh para pengacara yang mempergunakan honorarium atau mendapatkan pembayaran sejumlah uang dari klien. ${ }^{12}$

Penyelenggaraan pemberian bantuan hukum yang diberikan kepada penerima bantuan hukum merupakan upaya untuk mewujudkan hak-hak konstitusi dan sekaligus sebagai implementasi negara hukum yang mengakui dan melindungi serta menjamin hak warga negara akan kebutuhan akses terhadap keadilan dan kesamaan di hadapan hukum. Bantuan hukum pula merupakan pelayanan hukum yang bertujuan untuk memberikan perlindungan hukum dan pembelaan terhadap hak-hak konstitusi tersangka / terdakwa sejak ia ditahan sampai diperolehnya putusan pengadilan yang tetap. Yang dibela dan diberi perlindungan hukum bukan kesalahan tersangka / terdakwa melainkan hak tersangka / terdakwa agar terhindar dari perlakuan dan tindakan tidak terpuji atau tindakan sewenang-wenang dari aparat penegak hukum.Jadi meskipun tersangka / terdakwah memang terbukti bersalah, mereka tetap memiliki hak untuk mendapatkan bantuan hukum.

12 Sukinta, Peranan Lembaga Bantuan Hukum Bagi Masyarakat Dalam Memperoleh Keadilan (Semarang: Fakultas Hukum Universitas Diponegoro, 1997). Hlm. 4 
Dalam Pasal 27 Ayat (1) UUD 1945, dikatakan bahwa: "Segala warga negara bersamaan kedudukannya di dalam hukum dan pemerintahan serta wajib menjunjung hukum dan pemerintahan itu dengan tidak ada kecualinya". ${ }^{13}$

Sementara itu fakir miskin merupakan tanggung jawab negara yang diatur dalam Pasal 34 UUD 1945, yang berbunyi: "Fakir miskin dan anak-anak yang terlantar dipelihara oleh Negara". ${ }^{14}$

Peranan Lembaga Bantuan Hukum dalam memberikan bantuan hukum secara cuma-cuma terhadap masyarakat yang tidak mampu dalam proses perkara pidana dinyatakan dalam KUHAP, dimana di dalamnya dijelaskan bagi mereka yang tidak mampu dan tidak mempunyai penasihat hukum sendiri maka pejabat yang bersangkutan pada semua tingkat pemeriksaan dalam proses peradilan wajib menunjuk penasihat hukum bagi mereka, hal tersebut terdapat dalam Pasal 56 Ayat (2) yang menyatakan : "Setiap penasihat hukum yang ditunjuk untuk bertindak sebagaimana dimaksud dalam Ayat (1), memberikan bantuannya dengan cuma-cuma".

Pemberian bantuan hukum oleh Lembaga Bantuan Hukum memiliki peranan yang sangat besar yaitu untuk mendampingi kliennya sehingga dia tidak akan diperlakukan dengan sewenang-wenang oleh aparat, demikian juga untuk membela dalam hal materinya yang mana di sini diharapkan dapat tercapainya keputusan yang mendekati rasa keadilan dari pengadilan. Terkait konteks penyelenggaraan pendanaan untuk Lembaga Bantuan Hukum dibebankan kepada Anggaran Pendapatan dan Belanja Negara (APBN). Alokasi dana APBN untuk penyelenggaraan bantuan hukum adalah wujud kewajiban pemerintah dan disalurkan melalui anggaran Kementerian Hukum dan Hak Asasi Manusia Republik Indonesia sebagai penyelenggara bantuan hukum. Sumber pendanaan bantuan hukum selain dari APBN,dapat diperoleh

\footnotetext{
${ }^{13}$ Pasal 27 Ayat (1) Undang-Undang Dasar Negara Republik Indonesia Tahun 1945

${ }^{14}$ Pasal 34 Undang-Undang Dasar Negara Republik Indonesia Tahun 1945
} 
juga dari Pemerintah Daerah tingkat I (Propinsi) dan Tingkat II (Kabupaten, Kota), namun dalam proses pemberian akreditas dan verifikasi tetap mengacu pada Kementerian Hukum dan Hak Asasi Manusia Republik Indonesia. Selanjutnya pengaturan lebih lanjut mengenai tata cara penyaluran dana bantuan hukum diatur dengan Peraturan Pemerintah.

Sesuai Peraturan Pemerintah Nomor 42 Tahun 2013, anggaran bantuan hukum diberikan untuk litigasi dan non-litigasi, besaran anggaran bantuan hukum di tentukan oleh Menteri sesuai dengan ketentuan peraturan perundang-undangan mengenai standar biaya. Berdasarkan Keputusan Menteri Hukum dan Hak Asasi Manusia Republik Indonesia biaya kegiatan bantuan hukum litigasi untuk pemberi bantuan hukum dalam satu perkara pidana, perdata dan tata usaha negara, hingga perkara itu mempunyai kekuatan hukum mengikat. Selain itu bantuan hukum juga diberikan untuk perkara Non Litigasi meliputi penyuluhan hukum, konsultasi hukum, investiasi perkara, baik secara elektronik maupun non-elektronik, penelitian hukum, mediasi, negosiasi, pemberdayaan masyarakat, pendampingan di luar pengadilan dan/atau drafting dokumen hukum.

Dengan adanya bantuan hukum yang diberikan oleh negara melalui Kementerian Hukum dan Hak Asasi Manusia Republik Indonesia diharapkan semua lapisan masyarakat yang kurang mampu untuk mencari keadilan dan kesetaraan dimuka hukum dapat terpenuhi hakhaknya sebagaimana diamanatkan dalam Undang-Undang Dasar Republik Indonesia.

Berdasarkan keputusan Direktur Jendral Badan Peradilan Umum Nomor : 1/DJU/OT 01.3/VIII/2011 tentang petunjuk pelaksanaan Surat Edaran Mahkamah Agung Republik Indonesia Nomor 10 Tahun 2010 Tentang Pedoman Bantuan Hukum Lampiran A, majelis Hakim menetapkan dan menunjuk Advokat untuk memberikan jasa bantuan hukum dan membuat surat kuasa khusus guna bertindak mewakili, 
mendampingi, membela dan melakukan tindakan hukum lainnya untuk kepentingan Terdakwa selaku pemohon bantuan hukum. Penetapan dan penunjukan Advokat di atas wajib dilengkapi dengan :

\subsubsection{Surat Kuasa Khusus.}

5.1.2. Surat Keterangan Tidak Mampu dari Lurah atau Kepala Desa setempat atau Kartu Keluarga Miskin (KKM), atau Kartu Jaminan Kesehatan Masyarakat (Jamkesmas), atau Kartu Keluarga Harapan (KKH), atau Kartu Bantuan Langsung Tunai (BLT) atau Surat Pernyataan Tidak Mampu yang dibuat dan ditandatangani pemohon bantuan hukum dan diketahui oleh Ketua Pengadilan Negeri.

Berdasarkan Penetapan Penunjukan Advokat untuk memberikan jasa bantuan hukum tersebut, selanjutnya dikeluarkan pula :

5.1.1. Penetapan Ketua Pengadilan Negeri yang memerintahkan Kuasa Pengguna Anggaran untuk membayar dana bantuan hukum kepada Advokat yang telah ditunjuk untuk memberikan jasa bantuan hukum kepada Terdakwa.

5.1.2. Panitera / Sekretaris Pengadilan Negeri selaku Kuasa Pengguna Anggaran membuat Surat Keputusan Pembebanan Dana Bantuan Hukum tersebut ke DIPA pengadilan.

Pencairan anggaran Bantuan Hukum kepada Advokat dilakukan setelah perkara diputus oleh Pengadilan Negeri dengan melampirkan :

5.1.1. Surat Kuasa Khusus.

5.1.2. Surat Keterangan Tidak Mampu dari Lurah atau Kepala Desa setempat atau Kartu Keluarga Miskin (KKM), atau Kartu Jaminan Kesehatan Masyarakat (Jamkesmas), atau Kartu Keluarga Harapan (KKH), atau Kartu Bantuan Langsung Tunai (BLT) atau Surat Pernyataan Tidak Mampu yang dibuat dan ditandatangani pemohon bantuan hukum dan diketahui oleh Ketua Pengadilan Negeri. 
5.1.3. Penetapan Majelis Hakim untuk Penunjukan Advokat yang menjalankan kuasa penerima bantuan hukum.

5.1.4. Salinan/Petikan Putusan Perkara tersebut.

Komponen yang dibiayai dan dibayarkan dengan Anggaran Dana Bantuan Hukum untuk kepentingan pemohon bantuan hukum dalam proses pemeriksaan di Pengadilan Negeri terdiri dari Advokat, Saksi, Saksi Ahli, dan Penerjemah.Saksi yang dimaksud di dalam angka 4 adalah saksi yang meringankan Terdakwa. Anggaran Dana Bantuan Hukum yang dialokasikan untuk empat komponen diatas merupakan biaya transport.

Pengaturan pengeluaran dana Bantuan hukum sebesar Rp. 1.000.000,- (satu juta rupiah) untuk empat komponen tersebut diperinci masing-masing sebagai berikut:

5.1.1. Advokat sebesar Rp. 600.000,- (enam ratus ribu rupiah) ;

5.1.2. Saksi maksimal sebesar Rp. 200.000,- (dua ratus ribu rupiah)

5.1.3. Saksi Ahli maksimal sebesar Rp. 100.000,-(seratus ribu rupiah).

5.1.4. Penerjemah maksimal sebesar Rp. 100.000,- (seratus ribu rupiah).

Pengeluaran/pencairan uang oleh Bendahara Pengeluaran Pengadilan Negeri untuk biaya Saksi Adecharge, atau Saksi Ahli atau Penterjemah tersebut harus dilengkapi dengan Penetapan Majelis Hakim dan/atau berita acara persidangan Saksi Adecharge, atau Saksi Ahli, atau Penerjemah serta menanda tangani kwitansi tanda bukti pengeluaran.

Bendahara Pengeluaran mencatat dan membukukan semua pengeluaran dalam buku register khusus dan menyimpan bukti-bukti yang berkaitan.

\subsection{Subjek Hukum yang Bisa Mengajukan Bantuan Hukum}

Pemberian bantuan hukum harus sesuai dan tepat sasaran. Dalam artian bahwa orang yang mendapatkan bantuan hukum, sebagaimana 
tujuan dari pemberian bantuan hukum itu harus orang-orang yang sesuai dengan kriteria yang dimaksud dalam Undang-Undang. Menurut Pasal 5 Undang-Undang Bantuan Hukum, yang berhak mendapatkan bantuan hukum yaitu sebagai berikut:

5.2.1. Penerima Bantuan Hukum sebagaimana dimaksud dalam Pasal 4 ayat (1) meliputi setiap orang atau kelompok miskin yang tidak dapat memenuhi hak dasar secara layak dan mandiri.

5.2.2. Hak dasar sebagaimana dimaksud pada ayat (1) meliputi hak atas pangan, sandang, layanan kesehatan, layanan pendidikan, pekerjaan dan berusaha, dan/atau perumahan.

Dalam undang-undang bantuan hukum, penerima bantuan hukum tidak disebutkan secara jelas.Namun, pada prinsipnya harus mengacu pada ketentuan sebagaimana yang dimaksudkan di dalam Pasal 5 undang-undang bantuan hukum tersebut. Sehingga secara menyeluruh, kriteria subjek penerima bantuan hukum adalah sebagai berikut:

5.2.1. Orang yang memiliki masalah hukum keperdataan, pidana, dan tata usaha Negara, baik litigasi maupun non litigasi (mengacu pada Pasal 4 undang-undang bantuan hukum)

5.2.2. Orang-orang yang hak-hak konstitusionalnya dilanggar oleh oknum penegak hukum.

5.2.3. Orang-orang yang tidak mendapatkan akses untuk mendapatkan keadilan.

5.2.4. Orang-orang yang teraniaya oleh karena masalah hukum yang sedang dihadapinya.

Keempat kriteria ini bukan suatu syarat mutlak untuk mendapatkan bantuan hukum secara cuma-cuma. Sebab keempatnya harus tetap mengacu pada ketentuan dalam Pasal 5 ayat (1) Undang-Undang bantuan hukum, yaitu yang mendapatkan bantuan hukum adalah setiap orang atau kelompok yang benar-benar miskin, yang dibuktikan dengan persyaratan yang telah ditentukan. Negara mengakui adanya hak-hak dalam ekonomi, 
sosial, budaya, sipil dan politik bagi para fakir miskin, maka secara konstitusional orang miskin berhak untuk diwakili dan dibela baik didalam maupun diluar pengadilan (acces to legal counsel). Bantuan hukum bagi warga miskin termuat dalam Pasal 34 ayat (1) UUD'45. Jadi bantuan hukum adalah hak dari orang yang tidak mampu yang dapat diperoleh tanpa bayar (pro bono publico) sebagai penjabaran persamaan hak di hadapan hukum. Pasal 34 ayat (2) dan ayat (4) UUD 1945 bahwa negara mengembangkan sistem jaminan sosial bagi seluruh rakyat dan memberdayakan masyarakat yang lemah dan tidak mampu sesuai dengan martabat kemanusiaan yang diatur dalam UUBH. ${ }^{15}$

\subsection{Pihak yang Memberi Bantuan Hukum}

Dalam Undaug-Undang Nomor 18 Tahun 2003 tersebut mewajibkan seorang advokat atau penasihat hukum untuk memberikan bantuan hukum kepada masyarakat yang kurang mampu secara cuma-cuma berdasarkan syarat-syarat yang diatur dalam Undang-Undang.

Sesuai dengan defenisinya, bahwa advokat adalah orang yang berprofesi memberikan jasa hukum, baik di dalam maupun di luar pengadilan yang memenuhi persyaratan berdasarkan ketentuan UndangUndang. Itu artinya bahwa orang yang diperbolehkan memberikan bantuan hukum adalah advokat. Sehingga seorang advokat berdasarkan amanat Undang-Undang memiliki kewajiban untuk memberikan bantuan hukum kepada setiap orang yang membutuhkannya. Hal ini mengacu pada Pasal 22 Undang-Undang Advokat, yang menyatakan bahwa:

5.3.1. Advokat wajib memberikan bantuan hukum secara cumacuma kepada pencari keadilan yang tidak mampu.

5.3.2. Ketentuan mengenai persyaratan dan tata cara pemberian bantuan hukum secara cuma-cuma sebagaimana dimaksud

15 Iwan Wahyu Pujiarto, "Pelaksanaan Pemberi Bantuan Hukum Dikaitkan Dengan Undang-Undang No. 16 Tahun 2011 Tentang Bantuan Hukum," USU Law Journal 2, no. 3 (2015). Hlm. 87-88 
pada ayat (1), diatur lebih lanjut dengan Peraturan Pemerintah.

Namun pada kenyataanya masih banyak advokat yang tidak mau memberikan bantuan hukum secara cuma-cuma karena peraturan terkait pemberian bantuan hukum secara cuma-cuma tidak mengikat bagi setiap advokat. Seharusnya kewajiban untuk memberikan bantuan hukum harus memiliki konsekuensi mengikat bagi advokat tersebut. Sehingga apabila seorang advokat tidak bersedia melaksanakan kewajiban tersebut, maka harus mendapatkan konsekuensi etik. Meskipun selama ini, kode etik yang belum begitu menekankan pada kewajiban pemberian bantuan hukum oleh setiap advokat, menjadi celah bagi advokat untuk menghindari pemberian bantuan hukum.

Mengingat bantuan hukum hanya boleh diberikan oleh seorang advokat, sepantasnya setiap advokat harus menjalankannya dengan sebaik mungkin. Apalagi mengingat profesi advokat adalah profesi yang terhormat, sudah seharusnya memberikan pelayanan hukum bagi mereka yang membutuhkannya.

\section{Kesimpulan}

6.1. Berdasarkan penjelasan di atas, maka dapat disimpulkan bahwa Berdasarkan keputusan Direktur Jendral Badan Peradilan Umum Nomor: 1/DJU/OT 01.3/VIII/2011 tentang petunjuk pelaksanaan Surat Edaran Mahkamah Agung Republik Indonesia Nomor 10 Tahun 2010 tentang Pedoman Bantuan Hukum Lampiran A, majelis Hakim menetapkan dan menunjuk Advokat untuk memberikan jasa bantuan hukum dan membuat surat kuasa khusus guna bertindak mewakili, mendampingi, membela dan melakukan tindakan hukum lainnya untuk kepentingan Terdakwa selaku pemohon bantuan hukum. Penetapan dan penunjukan Advokat di atas wajib dilengkapi dengan Surat Kuasa Khusus serta Surat Keterangan Tidak Mampu dari Lurah atau Kepala Desa setempat atau Kartu Keluarga Miskin (KKM), atau Kartu Jaminan Kesehatan Masyarakat 
(Jamkesmas), atau Kartu Keluarga Harapan (KKH), atau Kartu Bantuan Langsung Tunai (BLT) atau Surat Pernyataan Tidak Mampu yang dibuat dan ditandatangani pemohon bantuan hukum dan diketahui oleh Ketua Pengadilan Negeri. Kemudian Penetapan Ketua Pengadilan Negeri yang memerintahkan Kuasa Pengguna Anggaran untuk membayar dana bantuan hukum kepada Advokat yang telah ditunjuk untuk memberikan jasa bantuan hukum kepada Terdakwa untuk selanjutnya Panitera / Sekretaris Pengadilan Negeri selaku Kuasa Pengguna Anggaran membuat Surat Keputusan Pembebanan Dana Bantuan Hukum tersebut ke DIPA pengadilan.

6.2. Secara menyeluruh, kriteria subjek penerima bantuan hukum adalah sebagai berikut: (1). Orang yang memiliki masalah hukum keperdataan, pidana, dan tata usaha Negara, baik litigasi maupun non-litigasi (mengacu pada Pasal 4 Undang-Undang Bantuan Hukum) (2). Orangorang yang hak-hak konstitusionalnya dilanggar oleh oknum penegak hukum. (3). Orang-orang yang tidak mendapatkan akses untuk mendapatkan keadilan. Serta (4). Orang-orang yang teraniaya oleh karena masalah hukum yang sedang dihadapinya.

6.3. Kemudian mengacu pada Pasal 22 Undang-Undang Advokat, yang menyatakan bahwa: (1). Advokat wajib memberikan bantuan hukum secara cuma-cuma kepada pencari keadilan yang tidak mampu. Serta (2). Ketentuan mengenai persyaratan dan tata cara pemberian bantuan hukum secara cuma-cuma sebagaimana dimaksud pada ayat (1), diatur lebih lanjut dengan Peraturan Pemerintah. 


\section{DAFTAR PUSTAKA}

\section{Buku}

Philipus M Hadjon. Perlindungan Hukum Bagi Rakyat Di Indonesia. Bandung: Bina Ilmu, 1987.

Sukinta. Peranan Lembaga Bantuan Hukum Bagi Masyarakat Dalam Memperoleh Keadilan. Semarang: Fakultas Hukum Universitas Diponegoro, 1997.

Frans Hendra Winarta. Hak Konstitusional Fakir Miskin Untuk Memperoleh Bantuan Hukum Dalam Rangka Pembangunan Hukum Nasional. Semarang: Universitas Padjajaran, 2007.

IGN. Ridwan Widyadharma. Profesional Hukum Dalam Pemberian Bantuan Hukum. Semarang: Badan Penerbit Universitas Diponegoro, 2010.

\section{Artikel Jurnal}

Iwan Wahyu Pujiarto. "Pelaksanaan Pemberi Bantuan Hukum Dikaitkan Dengan Undang-Undang No. 16 Tahun 2011 Tentang Bantuan Hukum." USU Law Journal 2, no. 3 (2015).

Satriawan, Andan Adi, Upik Hamidah, and Satria Prayoga. "Implementasi Bantuan Hukum Pada Masyarakat Miskin Di Kota Bandar Lampung (Studi Di Lembaga Bantuan Hukum Bandar Lampung).” Jurnal Online FH UNILA 1, no. 3 (2014).

Yusuf Saefudin. "Implementasi Pemberian Bantuan Hukum Bagi Rakyat Miskin Di Jawa Tengah Berdasarkan Undang-Undang Nomor 16 Tahun 2011 Tentang Bantuan Hukum.” Jurnal Idea Hukum 1, no. 1 (2015).

\section{Peraturan Perundang-undangan}

Undang-Undang Nomor 39 Tahun 1999 tentang Hak Asasi Manusia (HAM).

Undang-Undang Nomor 26 tahun 2000 tentang Pengadilan Hak Asasi Manusia.

Undang-Undang Nomor 4 Tahun 2004 tentang Kekuasaan Kehakiman. 
Undang-Undang Nomor 18 Tahun 2003 tentang Advokat.

Undang-Undang Nomor 16 Tahun 2011 tentang Bantuan Hukum.

Peraturan Pemerintah Nomor 43 Tahun 2013 tentang Syarat dan Tata Cara Pemberian Bantuan Hukum dan Penyaluran Dana Bantuan Hukum. 